\title{
Antigenotoxicity properties of Copaifera multijuga oleoresin and its chemical marker, the diterpene (-)-copalic acid
}

Jacqueline Morais Alves, Luís Fernando Leandro, Juliana Marques Senedese, Pâmela Tinti de Castro, Daiane Eleutério Pereira, Flávia Aparecida Resende, Débora Leite Campos, Jonas Joaquim Mangabeira da Silva, Eliana Aparecida Varanda, Jairo Kenupp Bastos, Sérgio Ricardo Ambrósio \& Denise Crispim Tavares

To cite this article: Jacqueline Morais Alves, Luís Fernando Leandro, Juliana Marques Senedese, Pâmela Tinti de Castro, Daiane Eleutério Pereira, Flávia Aparecida Resende, Débora Leite Campos, Jonas Joaquim Mangabeira da Silva, Eliana Aparecida Varanda, Jairo Kenupp Bastos, Sérgio Ricardo Ambrósio \& Denise Crispim Tavares (2018) Antigenotoxicity properties of Copaifera multijuga oleoresin and its chemical marker, the diterpene (-)-copalic acid, Journal of Toxicology and Environmental Health, Part A, 81:5, 116-129, DOI: 10.1080/15287394.2017.1420505

To link to this article: https://doi.org/10.1080/15287394.2017.1420505

Published online: 29 Dec 2017.

山ll Article views: 88
Submit your article to this journal $₫$ 


\title{
Antigenotoxicity properties of Copaifera multijuga oleoresin and its chemical marker, the diterpene (-)-copalic acid
}

\author{
Jacqueline Morais Alves ${ }^{a}$, Luís Fernando Leandroa, Juliana Marques Senedese ${ }^{a}$, Pâmela Tinti de Castroa, \\ Daiane Eleutério Pereiraa ${ }^{a}$ Flávia Aparecida Resende ${ }^{b}$, Débora Leite Camposc, \\ Jonas Joaquim Mangabeira da Silva ${ }^{d}$, Eliana Aparecida Varandac, Jairo Kenupp Bastos ${ }^{d}$, \\ Sérgio Ricardo Ambrósio ${ }^{a}$, and Denise Crispim Tavares ${ }^{\mathrm{a}}$
}

\begin{abstract}
aDepartamento de Ciências, Universidade de Franca, Franca, São Paulo, Brazil; bGrupo de Pesquisa em Química Medicinal e Medicina Regenerativa Universidade de Araraquara, Araraquara, São Paulo, Brazil; 'Departamento de Ciências Biológicas, Faculdade de Ciências Farmacêuticas de Araraquara, Universidade Estadual Paulista, Araraquara, São Paulo, Brazil; 'Departamento de Ciências Farmacêuticas, Faculdade de Ciências Farmacêuticas de Ribeirão Preto, Universidade de São Paulo, Ribeirão Preto, São Paulo, Brazil
\end{abstract}

\begin{abstract}
In view of the biological activities and growing therapeutic interest in oleoresin obtained from Copaifera multijuga, this study aimed to determine the genotoxic and antigenotoxic potential of this oleoresin (CMO) and its chemical marker, diterpene (-)-copalic acid (CA). The micronucleus (MN) assay in V79 cell cultures and the Ames test were used for in vitro analyses, as well as MN and comet assays in Swiss mice for in vivo analyses. The in vitro genotoxicity/mutagenicity results showed that either CMO (30, 60, or $120 \mu \mathrm{g} / \mathrm{ml}-\mathrm{MN}$ assay; $0.39-3.12 \mathrm{mg} / \mathrm{plate}-A m e s$ test) or CA (2.42; 4.84, or $9.7 \mu \mathrm{g} / \mathrm{ml}-\mathrm{MN}$ assay; 0.39-3.12 mg/plate-Ames test) did not induce a significant effect on the frequency of MN and number of revertants, demonstrating an absence of genotoxic and mutagenic activities, respectively, in vitro. In contrast, these natural products significantly reduced the frequency of $\mathrm{MN}$ induced by methyl methanesulfonate (MMS), and exerted a marked inhibitory effect against indirect-acting mutagens in the Ames test. In the in vivo test system, animals treated with CMO $(6.25 \mathrm{mg} / \mathrm{kg}$ b.w.) exhibited a significant decrease in rate of MN occurrence compared to those treated only with MMS. An antigenotoxic effect of CA was noted in the MN test ( 1 and $2 \mathrm{mg} / \mathrm{kg}$ b.w.) and the comet assay ( $0.5 \mathrm{mg} / \mathrm{kg} \mathrm{b.w.).} \mathrm{Data} \mathrm{suggest}$ that the chemical marker of the genus Copaifera, CA, may partially be responsible for the observed chemopreventive effect attributed to CMO exposure.
\end{abstract}

Abbreviations: 2-AA, 2-anthramine; 2-AF, 2-aminofluorene; $\mathrm{AFB}_{1}$, aflatoxin $\mathrm{B}_{1} ; \mathrm{B}[a] \mathrm{P}$, benzo[a] pyrene; $B O D$, biological oxygen demand; $B P D E$, benzo[a]pyrene-7,8-diol-9,10-epoxide; CA, (-)-copalic acid; CMO, oleoresin of Copaifera multijuga, DMEM, Dulbecco's Modified Eagles's Medium; DMSO, dimethylsulfoxide; EMBRAPA, Brazilian agricultural research corporation; GCMS, gas chromatography-mass spectrometry; HAM-F10, nutrient mixture F-10 Ham; HPLC, high performance liquid chromatography; LC-MS, liquid chromatography-mass spectrometry; MI, mutagenic index; MMC, mitomycin C; MMS, methyl methanesulfonate; MN, micronucleus; MNPCE, micronucleated polychromatic erythrocyte; NCE, normochromatic erythrocyte; NDI, nuclear division index; NMR, nuclear magnetic resonance; NPD, 4-nitro-o-phenylenediamine; PBS, phosphate-buffered saline; PCE, polychromatic erythrocyte; SA, sodium azide; V79, Chinese hamster lung fibroblast.

\section{ARTICLE HISTORY}

Received 23 October 2017

Revised 19 December 2017

Accepted 19 December 2017

\section{KEYWORDS}

Copaifera multijuga Hayne;

(-)-copalic acid; genotoxicity; antigenotoxicity; micronucleus test; Ames test; comet assay

\section{Introduction}

Epidemiological studies have shown an interactive association between dietary habits, lifestyle and genetics with the increased risk of many different chronic diseases, including cancer. The most consistent finding regarding diet as a determinant of cancer risk prevention is the relationship between consumption of vegetables and fruits and reduced risk of several types of cancers (Ben et al. 2015; Fagundes et al. 2017; Kok et al. 2010; Oliveira De Quadros et al. 2017; Venancio et al. 2016). Knowledge of the relationship between diet and cancer has advanced in recent years, but much remains to be elucidated with respect to diet and dietary components in cancer prevention. Evidence from clinical trial outcomes, epidemiological observations, preclinical models, and cell

CONTACT Denise Crispim Tavares denisecrispim2001@yahoo.com Departamento de Ciências, Universidade de Franca, Franca, São Paulo, 14404-600, Brazil

Color versions of one or more of the figures in the article can be found online at www.tandfonline.com/UTEH.

(๑) 2017 Taylor \& Francis 
culture systems all provided clues regarding the biology and mechanisms involved in cancer prevention (Mayne, Playdon, and Rock 2016; Ross 2010).

Plants, vegetables, and spices used in folk and traditional medicine have gained wide acceptance as one of the main sources for discovery and development of chemopreventive drugs (Aruoma et al. 2006; Farombi and Owoeye 2011; Niwa et al. 2016). Copaiba oil, extracted from trees of the genus Copaifera (family Leguminosae-Caesalpinoideae), has become important in Brazilian herbal medicine (Gonela et al. 2013). Different ethnopharmacological properties of the oil, such as anti-inflammatory, wound healing, antitumor (Leandro et al. 2012), trypanocidal (Izumi et al. 2013), and antimicrobial activity (Bardají et al. 2016), have been documented. Copaifera multijuga is found throughout the Brazilian territory, and its oleoresin displays a range of pharmacological properties, including antitumor (Lima et al. 2003), antineoplastic (Gomes et al. 2008), antinociceptive and antiinflammatory (Gomes et al. 2010), antimicrobial (Otaguiri et al. 2017), and antileishmanial activities (Albuquerque et al. 2017).

The chemical composition of Copaifera spp. oleoresin is characterized as a mixture of a predominant fraction of sesquiterpenes and diterpenes, including (-)-copalic acid (CA; Figure 1). The latter is considered a biomarker for the oleoresin of the genus (Leandro et al. 2012; Vargas et al. 2015; Veiga Jr et al., 2007). Biological properties such as antibacterial (Abrão et al. 2015; Souza et al. 2011a, 2011b; Tincusi et al. 2002), antitrypanosomal (Sartorelli et al. 2010), and antiproliferative

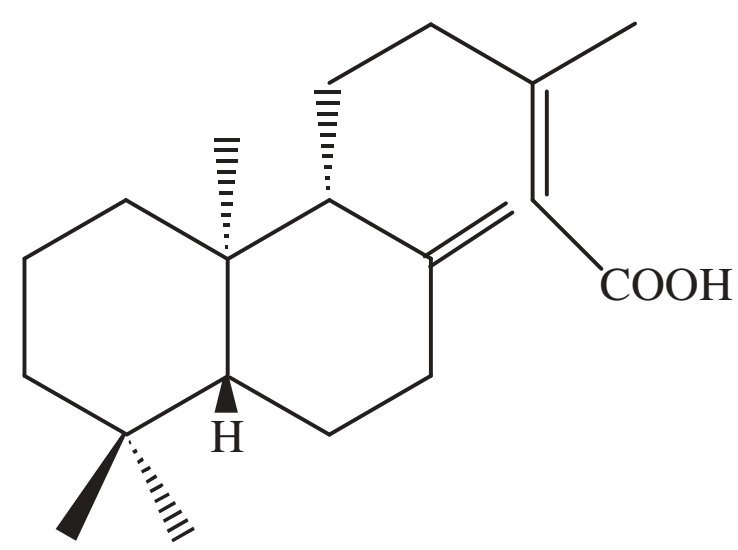

Figure 1. Chemical structure of (-)-copalic acid. activity in cancer cell lines (Abrão et al. 2015) have been reported for CA.

In view of the use of the oleoresin derived from C. multijuga (CMO) as a source of potential bioactive compounds, as well as the biological efficacy of CA, the aim of the present study was to examine the genotoxic/mutagenic and antigenotoxic/antimutagenic potential of these natural products utilizing in vitro micronucleus (MN) test in V79 cell cultures, Ames test, and in vivo $\mathrm{MN}$ and comet assays in Swiss mice.

\section{Materials and methods}

\section{Collection of oleoresin, isolation and identification of (-)-copalic acid}

Obtainment of C. multijuga oleoresin and identification of plant material

Copaifera multijuga Hayne oleoresin was collected in Manacapuru (S03 $\left.{ }^{\circ} 11.858^{\prime} \quad \mathrm{W}^{\prime} 60^{\circ} 35.437^{\prime}\right)$ Amazonas. The identification of the plant material was undertaken by Silvana Tavares Rodrigues at the Herbarium of the Brazilian Agricultural Research Corporation (EMBRAPA) in Belém, Pará, Brazil, where a voucher specimen was deposited under the number NID: 62/2013.

\section{Isolation of (-)-copalic acid from C. multijuga oleoresin and its identification}

The chromatographic process to isolate CA was previously reported by Alves et al. (2017). Briefly, $100 \mathrm{~g}$ of crude oleoresin were fractionated on Vacuum Liquid Chromatography using a gradient elution with hexanes and ethyl acetate. The rich CA fraction was re-chromatographed over open silica gel column to furnish $857 \mathrm{mg}$ of CA, which was identified by Nuclear Magnetic Resonance (NMR) of ${ }^{1} \mathrm{H}$ and ${ }^{13} \mathrm{C}$ analyses. The purity of $\mathrm{CA}$ was estimated to be greater than $95 \%$ by both HPLC and ${ }^{13} \mathrm{C}$ NMR analyses (Alves et al. 2017). Specific rotation $[\alpha]_{D}$ was measured using a polarimeter (Jasco P-2000, serial no. A104161232, Japan) at $25^{\circ}$ $\mathrm{C}$ and at $589 \mathrm{~nm}$, as $[\alpha]_{D}^{25}-31,38^{\circ}\left(c 0.42, \mathrm{CHCl}_{3}\right)$.

\section{DNA damage-inducing agent}

Methyl methanesulfonate (MMS, Sigma-Aldrich) was dissolved in phosphate buffered saline (PBS, 
$\mathrm{pH}$ 7.4) and used at concentrations of 110 and 44 $\mu \mathrm{g} / \mathrm{ml}$ in the clonogenic survival assay and MN test using V79 cells, respectively. For the bone marrow MN test, animals were treated with $40 \mathrm{mg}$ MMS/ $\mathrm{kg}$ body weight (b.w.) (Leandro et al. 2013).

In the Ames test, the standard mutagens used were 4-nitro-o-phenylenediamine (NPD, $10 \mu \mathrm{g} /$ plate), sodium azide (SA, $1.25 \mu \mathrm{g} /$ plate), mitomycin $\mathrm{C}(\mathrm{MMC}, 0.5 \mu \mathrm{g} /$ plate), benzo[a]pyrene $(\mathrm{B}[\mathrm{a}]$ $\mathrm{P}, 1.0 \mu \mathrm{g} /$ plate), 2-anthramine (2-AA, $1.25 \mu \mathrm{g} /$ plate), aflatoxin $\mathrm{B}_{1}\left(\mathrm{AFB}_{1}, 0.5 \mu \mathrm{g} /\right.$ plate $)$, and 2aminofluorene (2-AF, $10 \mu \mathrm{g} /$ plate), all purchased from Sigma-Aldrich.

\section{In vitro test system}

\section{Cells and culture conditions}

Chinese hamster lung fibroblasts (V79 cells) were kindly supplied by Prof. Dr. I.M.S. Cólus (Universidade Estadual de Londrina, Paraná, Brazil). Cells were maintained as monolayers in plastic culture flasks $\left(25 \mathrm{~cm}^{2}\right)$ in HAM-F10 (Sigma-Aldrich) and DMEM (Sigma-Aldrich) (1:1) medium supplemented with $10 \%$ fetal bovine serum (Nutricell), antibiotics $(0.01 \mathrm{mg} /$ $\mathrm{ml}$ streptomycin and $0.005 \mathrm{mg} / \mathrm{ml}$ penicillin; Sigma-Aldrich), and $2.38 \mathrm{mg} / \mathrm{ml}$ HEPES (Sigma-Aldrich) at $37^{\circ} \mathrm{C}, \mathrm{pH} 7.3$, in a BOD type incubator. The average cell cycle time was $12 \mathrm{~h}$ under these conditions. The MN assay was performed using cells grown in $5 \mathrm{ml}$ culture medium. In the comet assay, the cells were grown in culture tubes with a flat surface $(110 \times 16 \mathrm{~mm})$ containing $2.5 \mathrm{ml}$ culture medium according to the specifications described above.

\section{Clonogenic survival assay}

The clonogenic survival assay was used to determine the cytotoxicity of CMO. Cell cultures were treated with $\mathrm{CMO}$ concentrations ranging from 7.5 to $1920 \mu \mathrm{g} / \mathrm{ml}$. Negative, solvent (Tween 80; Synth; 0.25\%), and positive (MMS, $110 \mu \mathrm{g} / \mathrm{ml}$ ) controls were included. After treatment for $3 \mathrm{~h}$, cultures were trypsinized. Cells were counted using a light microscope with $\mathrm{X} 40$ objective in a Neubauer chamber and 300 cells seeded per culture flask (three flasks per concentration). The flasks were observed daily with a microscope objective for 10 days. After this period, the culture medium was removed, and colonies were washed with cold PBS and stained with Giemsa (1:20 phosphate buffer, $\mathrm{pH} \mathrm{7)} \mathrm{for} 20 \mathrm{~min}$. The colonies were counted with a magnifying glass (Franken et al. 2006).

\section{Micronucleus (MN) test}

The concentrations $(30,60$, or $120 \mu \mathrm{g} / \mathrm{ml})$ used for genotoxicity assessment at chromosomal level were selected based upon previous clonogenic survival cytotoxic assays, where concentrations higher than $120 \mu \mathrm{g} / \mathrm{ml}$ exerted a toxic effect on the cells. The concentrations of CA were 2.42, 4.84, and $9.7 \mu \mathrm{g} / \mathrm{ml}$, considering that the amount of CA in $\mathrm{CMO}$ is approximately $8 \%$. Negative, solvent (Tween 80, 0.25\%), and positive (MMS, $44 \mu \mathrm{g} /$ $\mathrm{ml}$ ) controls were also included in the analysis. The treatment designs and cell harvest and fixation procedures described by Furtado et al. (2010) were used.

A total of 3000 binucleated cells were scored per treatment, corresponding to 1000 cells/treatment/ repetition. The criteria established by Fenech (2000) were employed for the analysis of $\mathrm{MN}$ and binucleated cells. The nuclear division index (NDI) was determined analyzing 500 cells per repetition, for a total of 1500 cells per treatment. Cells with well-preserved cytoplasm containing 1-4 nuclei were scored. The NDI was calculated according to Eastmond and Tucker (1989), utilizing the following formula:

$$
N D I=\frac{[M 1+2(M 2)+3(M 3)+4(M 4)]}{N}
$$

where $M 1-M 4$ is the number of cells with $1,2,3$, and 4 nuclei, respectively, and $N$ is the total number of viable cells.

\section{Ames test}

Mutagenic activity at the gene level was assessed by the Salmonella/microsome assay using Salmonella typhimurium tester strains TA98, TA100, TA97a, and TA102, with (+S9) and without (-S9) metabolic activation, and the preincubation method (Maron and Ames 1983). The tester strains were kindly provided by Dr. B.N. Ames (Berkeley, CA, USA). The strains were grown from frozen cultures overnight for $12-14 \mathrm{~h}$ in Oxoid Nutrient Broth No. 2. The metabolic 
activation mixture (S9 fraction), prepared from livers of Sprague-Dawley male rats, weighing approximately $200 \mathrm{~g}$, treated with the polychlorinated biphenyl mixture Aroclor 1254 (500 mg/kg), was purchased from Molecular Toxicology, Inc. (Boone, NC, USA) and freshly prepared before each test. The metabolic activation system consisted of $4 \%$ of $\mathrm{S} 9$ fraction, $1 \%$ of $0.4 \mathrm{M} \mathrm{MgCl}_{2}$, $1 \%$ of $1.65 \mathrm{M} \mathrm{KCl}, 0.5 \%$ of $1 \mathrm{M} \mathrm{D}$-glucose-6phosphate disodium, $4 \%$ of $0.1 \mathrm{M} \mathrm{NADP}, 50 \%$ of $0.2 \mathrm{M}$ phosphate buffer, and $39.5 \%$ sterile distilled water (Maron and Ames 1983).

Five different concentrations of CMO and CA (0.39-3.12 $\mathrm{mg} /$ plate) diluted in dimethylsulfoxide (DMSO; Sigma-Aldrich) were assayed. The concentrations were selected based upon a preliminary toxicity test. In all subsequent assays, the upper limit of the dose range tested was either the highest non-toxic dose or the lowest toxic dose determined in this preliminary assay. Toxicity was detected either as a reduction in the number of histidine revertants (His+), or as a thinning of the auxotrophic background (i.e., background lawn) (Mortelmans and Zeiger 2000). The different concentrations to be tested were added to $0.5 \mathrm{ml}$ of $0.2 \mathrm{M}$ phosphate buffer, or to $0.5 \mathrm{ml}$ of $4 \%$ of $\mathrm{S} 9$ mixture containing $0.1 \mathrm{ml}$ of bacterial culture and then incubated for $20-30 \mathrm{~min}$ at $37^{\circ} \mathrm{C}$. Next, $2 \mathrm{ml}$ of top agar was added, and the mixture was poured onto a plate containing minimal agar. The plates were incubated for $48 \mathrm{~h}$ at $37^{\circ} \mathrm{C}$, and the His+ revertant colonies were counted manually. All experiments were conducted in triplicate. In addition to statistical analysis, the mutagenic index (MI) was calculated for each concentration tested as the mean number of revertants per plate with the test compound divided by the mean number of revertants per plate with the negative (solvent) control. A test solution was defined as mutagenic when a concentration-response relationship was detected and a 2-fold increase in number of mutants ( $M I \geq 2$ ) was observed for at least one concentration (Santos et al. 2006). DMSO (50 $\mu \mathrm{l} /$ plate) served as the negative (solvent) control.

The antimutagenicity assay was conducted utilizing the same procedure as the mutagenicity assay, except that the natural products were combined with known mutagens in tests with and without metabolic activation. In these tests, the direct-acting mutagens were $10 \mu \mathrm{g}$ NPD/plate (for S. typhimurium TA98) and $0.5 \mu \mathrm{g} \mathrm{MMC} /$ plate (for S. typhimurium TA102) in the assay without metabolic activation. The indirect-acting mutagens were $1 \mu \mathrm{g} \mathrm{B}[\mathrm{a}] \mathrm{P} /$ plate (for S. typhimurium TA98) and $0.5 \mu \mathrm{g} \mathrm{AFB}_{1} /$ plate (for S. typhimurium TA100) in the assay with metabolic activation. All plates were incubated for $48 \mathrm{~h}$ at $37^{\circ} \mathrm{C}$, and the number of revertant colonies per plate was counted manually. This assay was performed in triplicate.

The antimutagenicity results are expressed as \% inhibition (the ability of the compounds to inhibit the activity of the known mutagen), calculated as follows:

$$
\text { Inhibition } \%: 100-[(\mathrm{T} / \mathrm{M}) \times 100]
$$

where $T$ is the number of revertant colonies in the plate containing the mutagen and compounds, and $M$ is the number of revertant colonies in the plate containing only the mutagen (Loh, Er, and Chen 2009). Inhibition less than $25 \%$ was classified as no antimutagenic effect, $25-40 \%$ as a moderate effect, and higher than $40 \%$ as strong antimutagenicity (Neigi, Jayaprakasha, and Jena 2003; Resende et al. 2012).

Cell viability was also determined for each antimutagenicity assay to assess the potential bactericidal effect of the mutagens. A substance was defined as bactericidal when bacterial survival was less than $60 \%$ of that noted in the negative control (Vargas et al., 1993, Resende et al. 2012).

\section{In vivo test system}

\section{Animals}

Male Swiss mice 7-8 weeks old with a body weight of approximately $25 \mathrm{~g}$ were provided by the Faculty of Pharmaceutical Sciences, University of São Paulo, Ribeirão Preto, São Paulo, Brazil. Animals were kept in plastic boxes in an experimental room under controlled conditions of temperature $\left(22 \pm 2^{\circ} \mathrm{C}\right)$ and humidity $(50 \pm 10 \%)$ on a 12-h light/dark cycle, with standard mouse chow and water available ad libitum. The experiment was conducted in accordance with internationally accepted guidelines for lab animals. The study protocol was approved by the Ethics Committee 
for Animal Care of the University of Franca (Protocol No. 017/10).

\section{Treatments}

The animals were divided into the following treatment groups of six animals each: negative control (water); positive control (MMS, $40 \mathrm{mg} / \mathrm{kg}$ b.w.); solvent control (Tween 80, 1\%); CMO (50 mg/kg b.w.) or CA (4 mg/kg b.w.); solvent solution plus MMS; CMO $(6.25,12.5,25$, or $50 \mathrm{mg} / \mathrm{kg}$ b.w.) plus MMS or CA $(0.5,1,2$, or $4 \mathrm{mg} / \mathrm{kg}$ b.w.) plus MMS. The doses were selected according to Alves et al. (2017). CMO, CA, and the solvent solution were administered by gavage $(0.5 \mathrm{ml} /$ animal $) 10 \mathrm{~min}$ before intraperitoneal (ip) injection of MMS $(0.3 \mathrm{ml} /$ animal). Bone marrow samples and hepatocytes were collected $24 \mathrm{~h}$ after treatment for the $\mathrm{MN}$ and comet assays, respectively. The bone marrow of young adult rodents is the target tissue for genetic damage using the MN test, since erythrocytes are produced in this tissue (OECD 474, 2016). The liver was selected to perform the comet assay as this tissue is the predominant organ involved in metabolism of substances and frequently a target organ for carcinogenicity (OECD 489, 2016).

\section{Micronucleus (MN) test}

The bone marrow MN test was performed according to the protocol described by MacGregor et al. (1987). A total of 2000 polychromatic erythrocytes (PCE) were analyzed per animal to determine the frequency of micronucleated polychromatic erythrocytes (MNPCE). The ratio of PCE/PCE + NCE (normochromatic erythrocytes) was calculated by the analysis of 400 erythrocytes to determine the cytotoxicity attributed to CMO and CA (Mersch-Sundermann et al. 2004). Slides were scored blindly under a light microscope with a $100 \times$ immersion objective.

\section{Comet assay}

For analysis of DNA damage, hepatocytes were obtained from Swiss mice as described by Sasaki et al. (1997). After preparation of the cell suspension, the comet assay procedures described and reviewed by Burlinson et al. (2007) were used. The slides were stained with $50 \mu \mathrm{l}$ Syber green $(20 \mu \mathrm{g} / \mathrm{ml})$ and covered with a coverslip. The stained nucleoids were immediately evaluated at $400 \times$ magnification under a Zeiss fluorescence microscope fitted with a 515-560 nm excitation filter and a 590-nm barrier filter. For each treatment, the extent and distribution of DNA damage indicated by the comet assay were evaluated by examining 50 images, which were captured intact and the nucleoid comet-shaped. The images were analyzed with the Comet Imager 2.2. The parameter considered was the percentage of DNA in the comet tail (\% DNA).

Hepatocyte viability after treatment was evaluated by Trypan blue staining. Briefly, a freshly prepared solution of $10 \mu$ Trypan blue $(0.4 \%)$ in distilled water was mixed with $10 \mu \mathrm{l}$ each cell suspension, spread onto a microscope slide, and covered with a coverslip. In this test, non-viable cells appear blue. At least 200 cells were counted per animal (Tsuboy et al. 2007).

\section{Calculation of \% reduction in DNA damage}

For the $\mathrm{MN}$ and comet assays, the \% reduction in MMS-induced damage by the natural products was calculated according to Waters et al. (1990) using the following formula:

$$
\% \text { Reduction }=\frac{A-B}{A-C} \times 100
$$

where $A$ corresponds to the DNA damage obtained for the treatment with MMS (positive control), $B$ is the group treated with natural product plus MMS, and $C$ is the negative control.

\section{Statistical analysis}

Data obtained in the clonogenic, $\mathrm{MN}$, and comet assays were analyzed statistically by analysis of variance for completely randomized experiments, with calculation of $\mathrm{F}$ statistics and respective $P$ values. In cases in which $P<0.05$, the treatment means were compared utilizing Tukey's test, and least significant difference was calculated for $P=0.05$. The results of the Ames test were analyzed using the Salanal 1.0 statistical software package (U.S. Environmental Protection Agency, Monitoring Systems Laboratory, Las Vegas, NV, from Research Triangle Institute, RTP, North Carolina, USA), adopting the model of Bernstein et al. (1982). Data (revertants/plate) were 
submitted to analysis of variance (ANOVA), followed by linear regression.

\section{Results}

\section{In vitro test system}

Concentration-dependent changes in the viability of CMO-treated cells were evaluated by the clonogenic survival assay. Each survival curve represents the mean of three independent experiments, and the bars indicate the standard error of the mean (Figure 2). Cultures treated with $7.5,15,30,60$, or $120 \mu \mathrm{g} \mathrm{CMO} / \mathrm{ml}$ did not differ significantly from negative control. In contrast, significant decreases were noted for cultures treated with 240, 480, 960, or $1920 \mu \mathrm{g} \mathrm{CMO} / \mathrm{ml}$ compared to negative control, demonstrating a cytotoxic action. Therefore, $\mathrm{CMO}$ concentrations of 30,60 , and $120 \mu \mathrm{g} / \mathrm{ml}$ were selected for further analysis in the genotoxicity and antigenotoxicity assays.

Figure 3 illustrates the frequencies of micronucleated binucleated V79 cells after exposure to $\mathrm{CMO}$ or $\mathrm{CA}$, alone or in combination with MMS. No marked alterations in the induction of MN were detected between cultures treated with the different concentrations of $\mathrm{CMO}$ and $\mathrm{CA}$, indicating absence of genotoxic activity at the concentrations tested. Furthermore, CMO (60 or $120 \mu \mathrm{g} / \mathrm{ml})$ and CA $(4.84$ or $9.7 \mu \mathrm{g} / \mathrm{ml})$

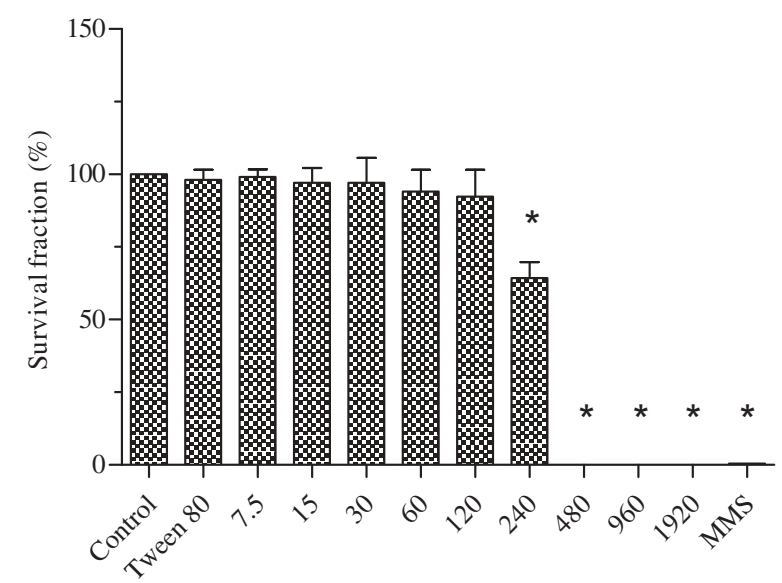

Figure 2. Percentage of survival of V79 cells treated with different concentrations $(\mu \mathrm{g} / \mathrm{ml})$ of Copaifera multijuga oleoresin (CMO) and their respective controls.

MMS, methyl methanesulfonate $(110 \mu \mathrm{g} / \mathrm{ml})$; Tween $80,0.25 \%$. *Significantly different from the negative control group $(P<0.05)$. significantly lowered the frequency of $\mathrm{MN}$ induced by MMS. The mean $\%$ reduction was $67 \%$ for CMO and $60 \%$ for CA. No significant difference in the NDI was found for any of the treated groups compared to negative control, indicating absence of cytotoxicity for different treatments under the present experimental conditions (data no shown).

Regarding the results of the Ames test, Table 1 presents the mean number of revertants/plate, standard deviation, and the MI after treatments with CMO or CA for S. typhimurium strains TA98, TA100, TA102, and TA97a in the presence (+S9) and absence (-S9) of metabolic activation. Both CMO and CA did not affect the number of revertant colonies compared to negative control suggesting an absence of mutagenicity.

The results regarding the antimutagenic potential of CMO and CA are shown in Table 2. Data are expressed as mean number of revertants/plate, standard deviation, and \% inhibition of mutagenicity for a strain treated with a mixture of CMO or CA plus mutagen compared to mutagenicity of mutagen alone. In experiments without metabolic activation (-S9), no marked reduction in the number of revertant colonies was observed for mutations induced with NPD and MMC in strains TA98 and TA102, respectively, indicating absence of antimutagenic activity against these mutagens. In contrast, $\mathrm{CMO}$ and $\mathrm{CA}$ at all concentrations tested exhibited potent significant inhibitory effects against the indirect-acting mutagens, $\mathrm{B}[\mathrm{a}] \mathrm{P}$ and $\mathrm{AFB}_{1}$, in strains TA98 and TA100, respectively.

In strain TA98, the antimutagenic activity of $\mathrm{CMO}$ against mutations induced by $\mathrm{B}[a] \mathrm{P}$ was similar to that of $\mathrm{CA}$, with the mutagenicity of $\mathrm{B}$ [a]P being significantly reduced from $62 \%$ to $76 \%$ for $\mathrm{CMO}$ and from $70 \%$ to $76 \%$ for CA. Furthermore, $\mathrm{CMO}$ and $\mathrm{CA}$ exhibited antimutagenic potential against the alkylating agent $\mathrm{AFB}_{1}$ in the presence of metabolic activation when strain TA100 was employed with inhibition ranging from $42 \%$ to $82 \%$ for $\mathrm{CMO}$ and from $61 \%$ to $83 \%$ for CA.

\section{In vivo test system}

The frequencies of MNPCE observed in bone marrow of Swiss mice treated with CMO or CA plus MMS are depicted in Figure 4. No significant 


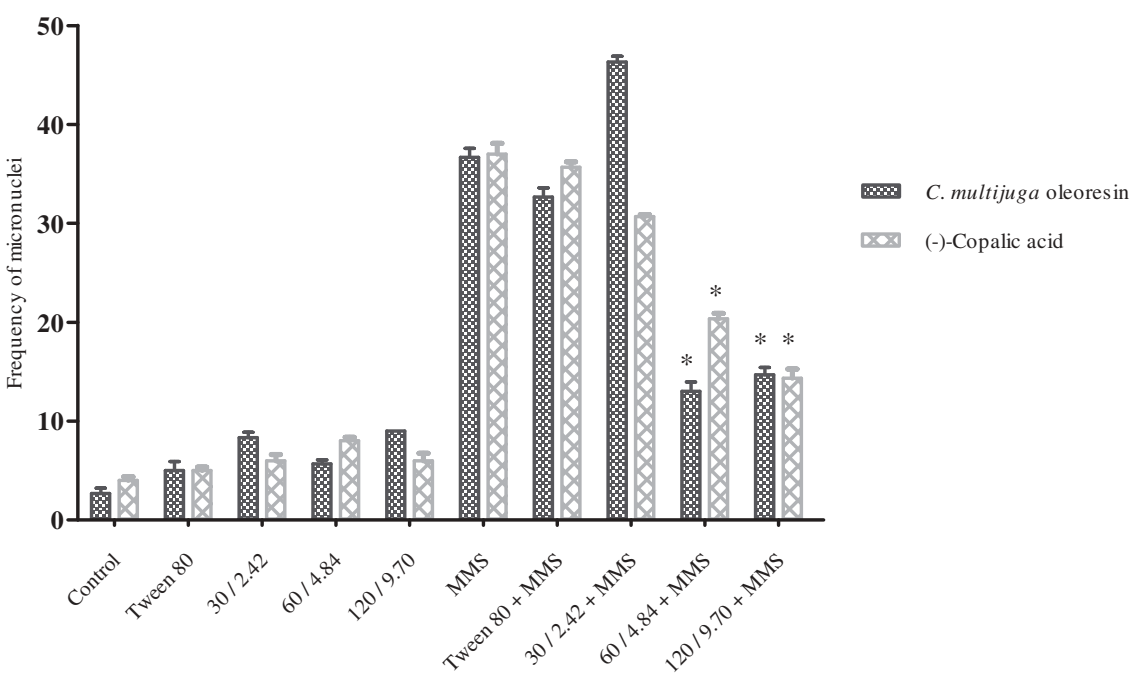

Figure 3. Frequency of micronuclei in V79 cell cultures treated with different concentrations ( $\mu \mathrm{g} / \mathrm{ml})$ of Copaifera multijuga oleoresin and (-)-copalic acid, alone and combined with MMS, and their respective controls.

MMS, methyl methanesulfonate $(44 \mu \mathrm{g} / \mathrm{ml})$; Tween $80,0.25 \%$.

*Significantly different from the MMS group $(P<0.05)$.

differences in frequency of MNPCEs were observed between animals treated with the highest dose of CMO $(50 \mathrm{mg} / \mathrm{kg})$ or CA $(4 \mathrm{mg} / \mathrm{kg})$ compared to negative control, indicating absence of genotoxic activity. Mice treated with different doses of CMO or CA plus MMS exhibited a significant decrease in frequency of MNPCE compared to those treated only with MMS. This reduction ranged from $19.17 \%$ to $52.33 \%$ for CMO and from $8.8 \%$ to $34.71 \%$ for CA. The differences were significant for the dose of $6.25 \mathrm{mg}$ $\mathrm{CMO} / \mathrm{kg}$ and doses of 1 and $2 \mathrm{mg} \mathrm{CA} / \mathrm{kg}$ (Figure 4). No marked change in \% PCE was detected in any of the treated groups compared to negative control, demonstrating an absence of cytotoxicity of the varying treatments under the conditions tested (data no shown).

The results obtained in the hepatocyte comet assay are shown in Figure 5. No marked alterations were found between animals treated with the highest dose of CMO $(50 \mathrm{mg} / \mathrm{kg})$ or CA $(4 \mathrm{mg} / \mathrm{kg})$ compared to negative control, demonstrating absence of genotoxicity. The mice treated with varying doses of CMO combined with MMS displayed frequencies of DNA damage that did not differ significantly from the group treated with MMS alone. Treatment with differing doses of CA and MMS diminished the extent of DNA damage compared to administration of MMS alone. This fall was significant only for treatment with the lowest dose of CA tested $(0.5 \mathrm{mg} / \mathrm{kg})$. Cell viability was higher than $95 \%$ for all treatments (data no shown).

\section{Discussion}

The experience with genetic toxicology testing over the past few decades has shown that no single test is able to detect all types of genotoxic effects. Thus, the potential of a chemical substance to induce genotoxicity is typically determined by using a battery of in vitro and in vivo tests (Witte et al. 2007). In this respect, the ability of CMO and its main chemical marker, the diterpene CA, to induce chromosome breakage or loss and primary DNA damage using the $\mathrm{MN}$ and comet assays, respectively, was investigated. In addition, the Ames test was employed to determine point mutations in S. typhimurium strains in the presence and absence of metabolic activation. These tests are important because of the need to assess the circumstances in which these substances exhibit beneficial or harmful effects.

In this study, CMO and CA were found not to be genotoxic as indicated by the frequency of $\mathrm{MN}$ in V79 cells. Furthermore, no mutagenic effects on the bacterial strains utilized in the Ames test were observed in the presence or absence of metabolic activation. Previously, Alves et al. (2017) found 


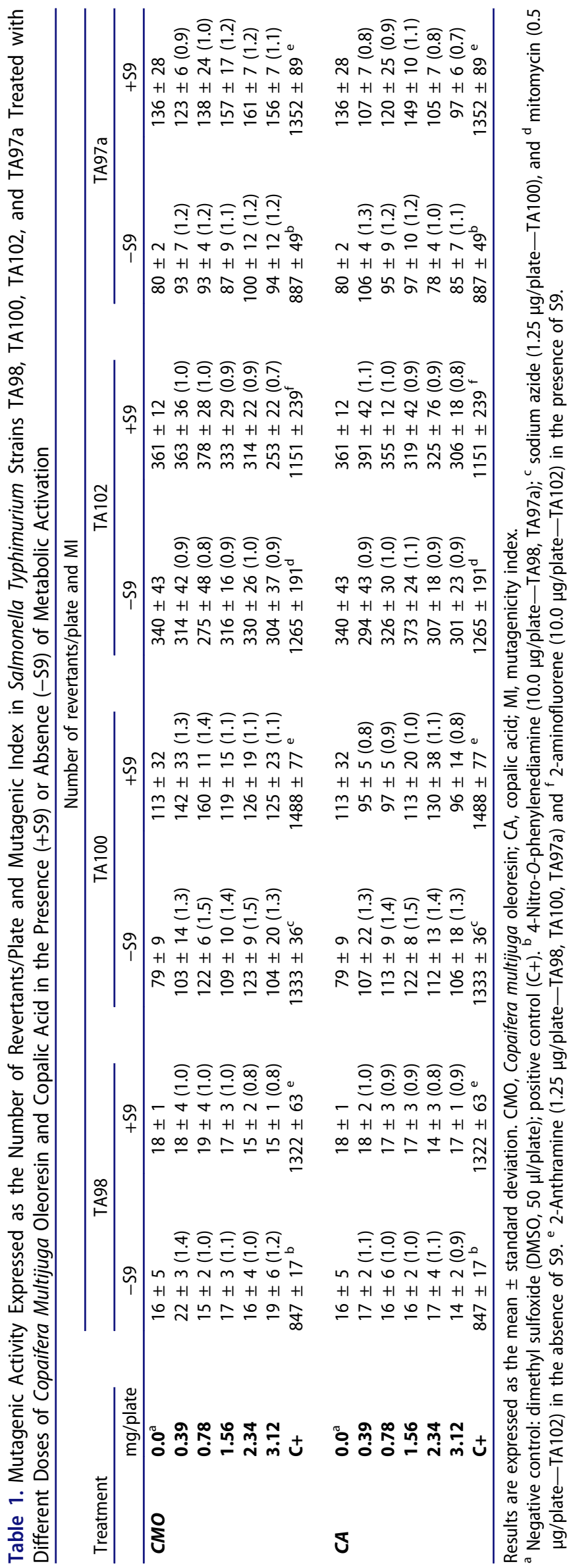


Table 2. Salmonella Typhimurium Revertants per Plate Treated with Copaifera Multijuga Oleoresin and Copalic Acid in Combination with Direct (-S9) and Indirect (+S9) Mutagens

\begin{tabular}{|c|c|c|c|c|c|c|c|}
\hline \multicolumn{8}{|c|}{ Salmonella typhimurium revertants/plate \pm SD (\% inhibition) } \\
\hline \multicolumn{5}{|c|}{ TA98 (-S9) } & \multicolumn{3}{|c|}{ TA102 (-S9) } \\
\hline \multicolumn{5}{|c|}{ Treatment } & atment & & \\
\hline \multicolumn{4}{|c|}{ DMSO $23 \pm 8$} & \multicolumn{4}{|c|}{ DMSO $288 \pm 47$} \\
\hline \multicolumn{4}{|c|}{ NPD $814 \pm 23$} & \multicolumn{4}{|c|}{ MMC $1039 \pm 40$} \\
\hline \multicolumn{2}{|c|}{ CMO + NPD } & \multicolumn{2}{|c|}{$C A+N P D$} & \multicolumn{2}{|c|}{ CMO + MMC } & \multicolumn{2}{|c|}{$C A+M M C$} \\
\hline 0.09 & $726 \pm 27\left(11^{a}\right)$ & 0.09 & $719 \pm 23\left(12^{\mathrm{a}}\right)$ & 0.09 & $1290 \pm 73$ & 0.09 & $1153 \pm 130$ \\
\hline 0.19 & $714 \pm 82\left(12^{\mathrm{a}}\right)$ & 0.19 & $701 \pm 36\left(14^{a}\right)$ & 0.19 & $1299 \pm 158$ & 0.19 & $1064 \pm 204$ \\
\hline 0.39 & $680 \pm 20(17 a)$ & 0.39 & $675 \pm 40\left(17^{\mathrm{a}}\right)$ & 0.39 & $1190 \pm 95$ & 0.39 & $904 \pm 145\left(13^{\mathrm{a}}\right)$ \\
\hline 0.78 & $681 \pm 14\left(16^{a}\right)$ & 0.78 & $677 \pm 28\left(17^{\mathrm{a}}\right)$ & 0.78 & $1026 \pm 55\left(1^{a}\right)$ & 0.78 & $868 \pm 77\left(16^{\mathrm{a}}\right)$ \\
\hline 1.56 & $680 \pm 19\left(16^{a}\right)$ & 1.56 & $668 \pm 39\left(18^{a}\right)$ & 1.56 & $939 \pm 22\left(10^{a}\right)$ & 1.56 & $756 \pm 81\left(27^{b}\right)$ \\
\hline \multicolumn{4}{|c|}{ TA98 (+S9) } & \multicolumn{4}{|c|}{ TA100 (+S9) } \\
\hline \multicolumn{4}{|c|}{ DMSO $33 \pm 6$} & \multicolumn{4}{|c|}{ DMSO $119 \pm 26$} \\
\hline \multicolumn{4}{|c|}{$\mathrm{B}[\boldsymbol{a}] \mathrm{P} 243 \pm 19$} & \multicolumn{4}{|c|}{$\mathbf{A F B}_{1} 1023 \pm 65$} \\
\hline \multicolumn{2}{|c|}{$\mathrm{CMO}+\mathrm{B}[a] \mathrm{P}$} & \multicolumn{2}{|c|}{$\mathrm{CA}+\mathrm{B}[\mathrm{a}] \mathrm{P}$} & \multicolumn{2}{|c|}{$\mathrm{CMO}+\mathrm{AFB}_{1}$} & \multicolumn{2}{|c|}{$C A+A F B_{1}$} \\
\hline 0.09 & $87 \pm 19\left(64^{c}\right)$ & 0.09 & $73 \pm 3\left(70^{c}\right)$ & 0.09 & $591 \pm 71\left(42^{c}\right)$ & 0.09 & $399 \pm 37\left(61^{c}\right)$ \\
\hline 0.19 & $93 \pm 16\left(62^{c}\right)$ & 0.19 & $68 \pm 12\left(72^{\mathrm{C}}\right)$ & 0.19 & $512 \pm 86\left(50^{c}\right)$ & 0.19 & $358 \pm 49\left(65^{\mathrm{c}}\right)$ \\
\hline 0.39 & $73 \pm 15\left(70^{c}\right)$ & 0.39 & $62 \pm 12\left(74^{c}\right)$ & 0.39 & $530 \pm 89\left(48^{c}\right)$ & 0.39 & $232 \pm 19\left(77^{c}\right)$ \\
\hline 0.78 & $68 \pm 20\left(72^{c}\right)$ & 0.78 & $68 \pm 21\left(72^{c}\right)$ & 0.78 & $493 \pm 29\left(52^{c}\right)$ & 0.78 & $175 \pm 28\left(83^{c}\right)$ \\
\hline 1.56 & $59 \pm 27\left(76^{c}\right)$ & 1.56 & $57 \pm 14\left(76^{c}\right)$ & 1.56 & $182 \pm 23\left(82^{\circ}\right)$ & 1.56 & $177 \pm 36\left(83^{\mathrm{c}}\right)$ \\
\hline
\end{tabular}

CMO, Copaifera multijuga oleoresin; CA, copalic acid (concentration in $\mathrm{mg} /$ plate); SD, standard deviation. NPD = 4-nitro-o-phenylenediamine (10.0 $\mu \mathrm{g} /$ plate $)$ and $\mathrm{MMC}=$ mitomycin $(0.5 \mu \mathrm{g} /$ plate $)$ in the absence of $\mathrm{S} 9(-\mathrm{S} 9) . \mathrm{B}[\mathrm{a}] \mathrm{P}=$ benzo[a]pyrene $(1.0 \mu \mathrm{g} / \mathrm{plate})$ and $\mathrm{AFB}_{1}=\mathrm{aflatoxin} \mathrm{B}_{1}(0.5 \mu \mathrm{g} /$ plate) in the presence of $59(+S 9)$. DMSO $=100 \mu \mathrm{l} /$ plate.

${ }^{a}$ No antimutagenic effect $\left(<25 \%\right.$ inhibition); ${ }^{b}$ moderate effect $\left(25-40 \%\right.$ inhibition); ${ }^{c}$ strong antimutagenic effect ( $>40 \%$ inhibition).

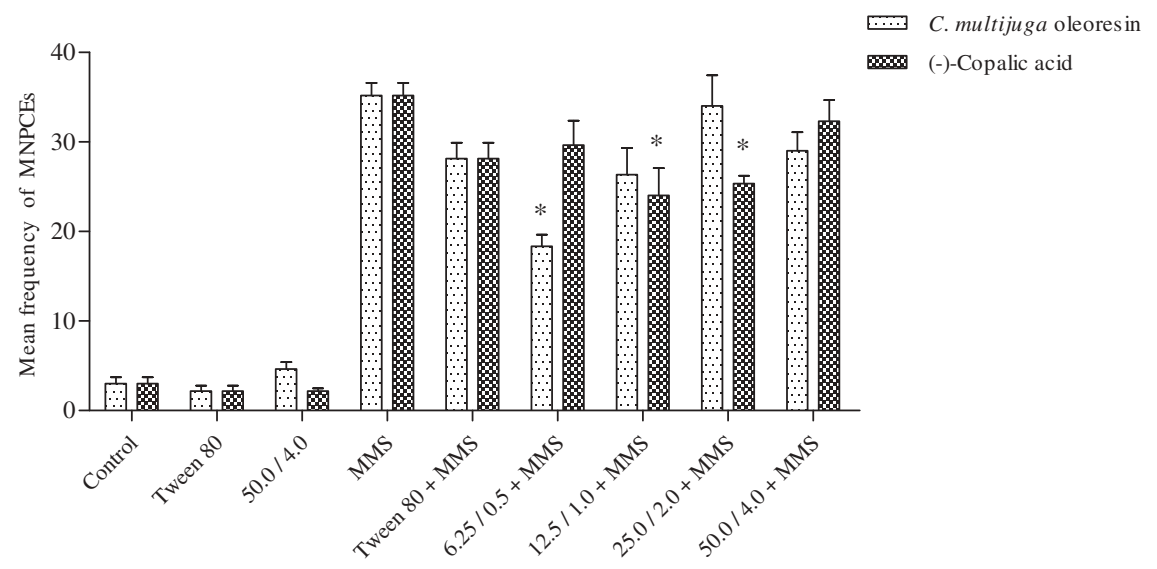

Figure 4. Mean frequencies of micronucleated polychromatic erythrocytes (MNPCEs) in bone marrow of animals treated with different doses $(\mathrm{mg} / \mathrm{kg}$ ) of Copaifera multijuga oleoresin or (-)-copalic acid combined with MMS and their respective controls.

MMS, methyl methanesulfonate (40 mg/kg b.w.); Tween $80,1 \%$.

*Significantly different from the MMS group $(P<0.05)$.

that subacute treatment with $\mathrm{CMO}$ or CA produced no marked genotoxic effects using peripheral blood MN. The absence of such effects in the assays used is the first step toward deciding whether utilization of these substances in traditional medicine is safe. Taking this into consideration, a study showing the absence of genotoxicity/ mutagenicity is highly relevant as the therapeutic properties of $C$. multijuga as an anticancer agent were reported antitumor (Lima et al. 2003) and antineoplastic (Gomes et al. 2008).

The present study also investigated the antigenotoxic potential of $\mathrm{CMO}$ and $\mathrm{CA}$ against known mutagenic agents. Treatment with $\mathrm{CMO}$ and $\mathrm{CA}$ plus MMS significantly reduced chromosomal damage in the MN test compared to MMS alone, demonstrating antigenotoxic activity. MMS has been used for decades as an experimental model 


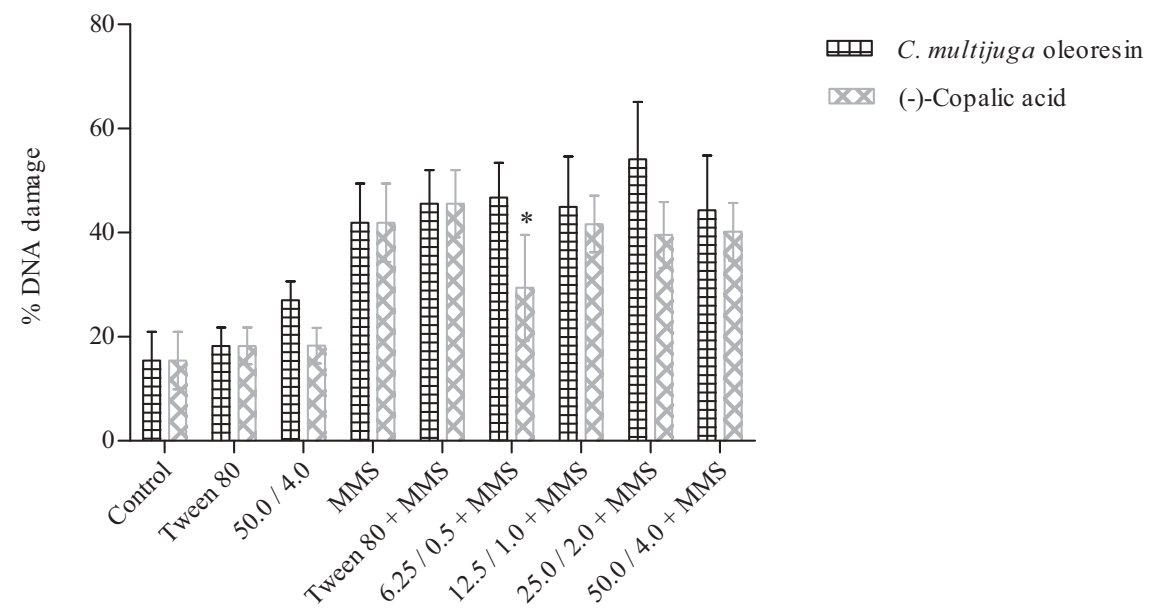

Figure 5. Percentage of DNA damage in the comet tail of hepatocytes after treatment with different concentrations (mg/kg) of Copaifera multijuga oleoresin or (-)-copalic acid combined with MMS and their respective controls.

MMS, methyl methanesulfonate (40 mg/kg b.w.); Tween 80, $1 \%$.

*Significantly different from the MMS group $(P<0.05)$.

compound to elucidate the mutagenic mechanisms of alkylating agents, potentially carcinogenic compounds that introduce lesions at nucleophilic centers of DNA owing to their electrophilic nature (Sobol et al. 2007). MMS is a monofunctional alkylating agent that acts directly to break DNA strands, leading to formation of monoadducts in DNA, as well as crosslinks that induce mutations involving different base substitutions (Mirzayans, Liuzzi, and Paterson 1998; Wyatt and Pittman 2006). The fact that MMS induces predominantly $\mathrm{N}$-methylations $\left(\mathrm{S}_{\mathrm{N}} 2\right.$ agent) indicates that $\mathrm{N}$-methylation lesions are responsible for its clastogenic effects (Kaina 2004). Therefore, a possible mechanism underlying the protective effect of CMO and CA against the genotoxicity induced by MMS is their ability to diminish alkylating DNA damage.

As reported by Gonçalves et al. (2014) and Silva et al. (2017), the major compounds detected in CMO oleoresin are sesquiterpenes $\beta$-caryophyllene and $\alpha$ copaene, as well as the diterpenes CA and (-)-3- $\beta$ acetoxy copalic acids, respectively. It is important to indicate that Copaifera oleoresin are composed of volatile and non-volatile fractions, predominantly containing sesquiterpenes and acid diterpenes, respectively. Therefore, it is important to know the relative concentration of both fractions in the crude oleoresin. For $\mathrm{CMO}$, it was observed that following hydrodistillation of the crude oleoresin using a Clevenger apparatus, this compound contained approximately $90 \%$ and $10 \%$ volatile and non-volatile fractions, respectively. In GC-MS analyses of the volatile fraction of our CMO sample, $45 \%$ of $\beta$-caryophyllene and $20 \%$ of $\alpha$-copaene was identified, and by LC-MS analyses of the non-volatile fraction $50 \%$ CA and $20 \%$ of (-)-3- $\beta$-acetoxy copalic acid was detected. In consideration of the total crude oleoresin, the major compounds are the sesquiterpene $\beta$-caryophyllene at approximately $40 \%$ and ditepene CA at approximately $5 \%$. Therefore, these two compounds may play an important role in the observed activities.

Di Sotto et al. (2010) showed that $\beta$-caryophyllene, the major constituent of $\mathrm{CMO}$, did not produce any cytotoxic or genotoxic effect in human lymphocyte cultures. In pre- and co-treatment protocols, this sesquiterpene was found to protect against ethyl methanesulfonate-induced DNA damage and was classified as a desmutagen. Di Sotto et al. (2010) postulated that an antioxidant effect, chemical interaction with the mutagen, or a membrane-destabilizing effect might contribute to the anticlastogenic activity of $\beta$-caryophyllene. Similarly, and in addition to the ability to induce detoxifying enzymes (Zheng, Kenney, and Lam 1992), $\beta$-caryophyllene may be responsible in part for the antigenotoxic effect of CMO noted in the present study.

In the Ames test, both $\mathrm{CMO}$ and $\mathrm{CA}$ did not inhibit mutagenesis mediated by direct-acting mutagens (NPD and MMC) under the conditions used in this study. However, the activity displayed was 
markedly increased by adding the microsomal fraction (S9) to the culture medium, which is a mammalian metabolic activation system. Data demonstrated a potent, concentration-independent inhibitory effect against $\mathrm{B}[\mathrm{a}] \mathrm{P}$ - and $\mathrm{AFB}_{1}$-induced mutagenicity.

$\mathrm{B}[\mathrm{a}] \mathrm{P}$ is one of the most potent and extensively studied carcinogens. In a cellular system, $\mathrm{B}[\mathrm{a}] \mathrm{P}$ is metabolized to the electrophilic metabolite, benzo[a] pyrene-7,8-diol-9,10-epoxide (BPDE), which covalently binds to DNA bases, primarily deoxyguanosine (Zahin et al. 2014). B[a]P, an organic tetracyclic hydrocarbon that is produced by incomplete combustion of organic matter, induces carcinogenicity in the lung. The metabolic products bind to DNA at guanine residues, and formation of DNA adducts increases mutations, which eventually enhance the risk of tumor initiation and progression (Chiu et al. 2016). There are at least two possible mechanisms by which $\mathrm{CMO}$ and $\mathrm{CA}$ might decrease $\mathrm{B}[\mathrm{a}] \mathrm{P}-\mathrm{DNA}$ adduct formation: (i) inhibition of P450 activity and/or enhancement of phase II enzymes, and (ii) direct conjugation with anti-BPDE.

$\mathrm{AFB}_{1}$, which is mainly produced by Aspergillus flavus, is a prevalent food contaminant (Dai et al. 2017). It is well-established $\mathrm{AFB}_{1}$ is associated with carcinogenic, teratogenic, and severe multi-organ toxicity properties (Dai et al. 2017; Unsal and BelgeKurutaş 2017; Vismara and Caloni 2007). The molecular toxicity attributed to $\mathrm{AFB}_{1}$ is primarily due to DNA alkylation and subsequent mutagenesis, as well as its prooxidant activities, which result in the generation of oxygen radicals (Zeinvand-Lorestani et al. 2015). CMO and CA also lowered the frequency of mutations induced by this fungal toxin in strain TA100 in the presence of metabolic activation, supporting the protective potential against indirect mutagens that require metabolic activation.

There are few apparent studies available regarding $\mathrm{CA}$, and this is the first to investigate its antigenotoxic potential using in vivo and in vitro assays. However, a number of investigators evaluated the protective effects of other diterpenes. Cavin et al. (2001) demonstrated the antigenotoxic properties of the coffee diterpenes, cafestol, and kahweol, against $\mathrm{AFB}_{1}$ genotoxicity in rat and human cells. These coffee diterpenoids also exhibited protective effects against carcinogens present in the human diet in humanderived hepatoma (HepG2) cells (Majer et al. 2005). In both cases, the antigenotoxic effects were attributed to inhibition of activating enzymes (cytochrome P450; sulfotransferase) and to induction of detoxifying enzymes. Nicolella et al. (2014) noted that manool, a labdane-type diterpene like CA, exerted a protective effect against chromosome damage induced by MMS in HepG2 cells, but not V79 cells. The differential effect of manool in V79 and HepG2 cells may be due, at least in part, to its ability to induce drugmetabolizing enzymes that are present to some extent in HepG2 cells (Nicolella et al. 2014).

Comparing the in vivo and in vitro results obtained for CMO and CA, data suggest that the diterpene is partially responsible for the antigenotoxic effect attributed to oleoresin. The antigenotoxic activity demonstrated in the treatment with the concentrations of $\mathrm{CMO}$ was also detected in the corresponding concentrations of CA. (-)-Copalic acid is the most abundant diterpene in CMO (Veiga et al. 2007).

Recently, Alves et al. (2017) showed that CMO and CA suppressed formation of pre-neoplastic lesions and exerted a protective effect against colon carcinogenesis in rats. When considering the role of DNA damage in the early stages of cancer, the chemopreventive effect of $\mathrm{CMO}$ and CA on colon carcinogenesis may be associated with their antigenotoxic properties.

Regarding the dose-response relationship in the present study, there were no significant differences between results obtained in the experiments with different doses of $\mathrm{CMO}$ or CA plus mutagen. The assessment of dose-effect relationships is complicated by the fact that many chemoprotective compounds act simultaneously at different protection levels (Knasmüller et al., 2002). On this basis, the lack of a dose-response relationship might be attributed to activation of different mechanisms dependent upon CMO and CA doses used.

In conclusion, data showed that, in addition to exerting no marked genotoxic effect in the Ames test, $\mathrm{MN}$ test or comet assay, CMO and CA were also effective in reducing genotoxicity induced by MMS in V79 cells and Swiss mice as well as mutagenesis mediated by indirect-acting mutagens $\left(\mathrm{B}[\mathrm{a}] \mathrm{P}\right.$ and $\left.\mathrm{AFB}_{1}\right)$ in the Ames test under the experimental conditions used. Furthermore, in vivo and in vitro studies are essential to better characterize the chemoprotective mechanism of C. multijuga oleoresin and of the diterpene CA in order to develop preventive interventions. 


\section{Funding}

This work was supported by São Paulo Research Foundation (grant \#2011/13630-7, FAPESP, Brazil). J.M. Alves thanks FAPESP for the PhD scholarship (grant \#2009/17237-8). The authors are grateful to Conselho Nacional de Desenvolvimento Científico e Tecnológico ( $\mathrm{CNPq}$ ) for their fellowships.

\section{Conflict of interest}

The authors declare that they have no actual or potential competing interests, financial or otherwise.

\section{References}

Abrão, F., L. D. A. Costa, J. M. Alves, J. M. Senedese, P. T. Castro, S. R. Ambrósio, R. C. S. Veneziani, J. K. Bastos, D. C. Tavares, and C. H. G. Martins. 2015. Copaifera langsdorffii oleoresin and its isolated compounds: Antibacterial effect and antiproliferative activity in cancer cell lines. BMC Complementary Alternative Medica 15:443.

Albuquerque, K. C., A. D. Veiga, J. V. Silva, H. P. Brigido, E. P. Ferreira, E. V. Costa, A. M. Marinho, S. Percário, and M. F. Dolabela. 2017. Brazilian amazon traditional medicine and the treatment of difficult to heal leishmaniasis wounds with Copaifera. Evidence Based Complementary Alternat Medica 2017:8350320.

Alves, J. M., J. M. Senedese, L. F. Leandro, P. T. Castro, D. E. Pereira, L. J. Carneiro, S. R. Ambrósio, J. K. Bastos, and D. C. Tavares. 2017. Copaifera multijuga oleoresin and its constituent diterpene (-)-copalic acid: Genotoxicity and chemoprevention study. Mutation Research 819:26-30.

Aruoma, O. I., B. Sun, H. Fuji, V. S. Neergheen, T. Bahorun, K. S. Kang, and M. K. Sung. 2006. Low molecular proanthocyamidin dietary biofactoroligonol: Its modulation of oxidative stress, bioefficacy, neuroprotection, food application and chemoprevention potentials. Biofactors 27:245-265.

Bardají, D. K. R., J. J. M. Silva, T. C. Bianchi, D. S. Eugênio, P. F. Oliveira, L. F. Leandro, H. L. G. Rogez, R. C. S. Veneziani, S. R. Ambrosio, D. C. Tavares, J. K. Bastos, and C. H. G. Martins. 2016. Copaifera reticulata oleoresin: Chemical characterization and antibacterial properties against oral pathogens. Anaerobe 40:18-27.

Ben, Q., J. Zhong, J. Liu, L. Wang, Y. Sun, L. Yv, and Y. Yuan. 2015. Association between consumption of fruits and vegetables and risk of colorectal adenoma: A PRISMA-compliant meta-analysis of observational studies. Medicine 94:e1599.

Bernstein, L., J. Kaldor, J. Mccann, and M. C. Pike. 1982. An empirical approach to the statistical analysis of mutagenesis data from the Salmonella test. Mutation Research 97:267-281.

Burlinson, B., R. R. Tice, G. Speit, E. Agurell, S. Y. BrendlerSchwaab, A. R. Collins, P. Escobar, M. Honma, T. S.
Kumaravel, M. Nakajima, Y. F. Sasaki, V. Thybaud, Y. Uno, M. Vasquez, and A. Hartmann. 2007. Fourth international workgroup on genotoxicity testing: Results of the in vivo Comet assay workgroup. Mutation Research 627:31-35.

Cavin, C., K. Mace, E. A. Offord, and B. Schilter. 2001. Protective effects of coffee diterpenes against aflatoxin B1-induced genotoxicity: Mechanisms in rat and human cells. Food and Chemical Toxicology 39:549-556.

Chiu, C. K., T. Y. Chen, J. H. Lin, C. Y. Wang, and B. S. Wang. 2016. Protective effects of five allium derived organosulfur compounds against mutation and oxidation. Food Chemistry 197:829-835.

Dai, Y., K. Huang, B. Zhang, L. Zhu, and W. Xu. 2017. Aflatoxin B1-induced epigenetic alterations: An overview. Food and Chemical Toxicology 109:683-689.

Di Sotto, A., G. Mazzanti, F. Carbone, P. Hrelia, and F. Maffei. 2010. Inhibition by beta-caryophyllene of ethyl methanesulfonate-induced clastogenicity in cultured human lymphocytes. Mutation Research 699:23-28.

Eastmond, D. A., and J. D. Tucker. 1989. Identification of aneuploidy-inducing agents using cytokinesis-blocked human lymphocytes and an antikinetochore antibody. Environmental and Molecular Mutagenesis 13:34-43.

Fagundes, G. E., A. P. Damiani, G. D. Borges, K. O. Teixeira, M. M. Jesus, F. Daumann, F. Ramlov, T. Carvalho, D. D. Leffa, P. Rohr, and V. Moraes De Andrade. 2017. Effect of green juice and their bioactive compounds on genotoxicity induced by alkylating agents in mice. Journal Toxicogical Environment Health A 80:756-766.

Farombi, E. O., and O. Owoeye. 2011. Antioxidative and chemopreventive properties of Vernonia amygdalina and garcinia biflavonoid. International Journal Environment Researcher Public Health 8:2533-2555.

Fenech, M. 2000. The in vitro micronucleus technique. Mutation Research 455:81-95.

Franken, N. A. P., H. M. Rodermond, P. Stap, J. Haveman, and C. Bree. 2006. Clonogenic assay of cells in vitro. Natural Protocols 1:2315-2319.

Furtado, R. A., F. R. Araújo, F. A. Resende, W. R. Cunha, and D. C. Tavares. 2010. Protective effect of rosmarinic acid on V79 cells evaluated by the micronucleus and comet assays. Journal Applications Toxicogical 30:254-259.

Gomes, N. M., C. M. Rezende, S. P. Fontes, A. M. Hovell, R. G. Landgraf, M. E. Matheus, A. C. Pinto, and P. D. Fernandes. 2008. Antineoplasic activity of Copaifera multijuga oil and fractions against ascitic and solid Ehrlich tumor. Journal Ethnopharmacol 119:179-184.

Gomes, N. M., C. M. Rezende, S. P. Fontes, M. E. Matheus, A. C. Pinto, and P. D. Fernandes. 2010. Characterization of the antinociceptive and anti-inflammatory activities of fractions obtained from Copaifera multijuga Hayne. Journal Ethnopharmacol 128:177-183.

Gonçalves, E. S., J. R. Silva, C. L. Gomes, M. B. L. Nery, D. M. A. F. Navarro, G. K. N. Santos, J. C. Silva-Neto, J. H. Costa-Silva, A. V. Araújo, and A. G. Wanderley. 2014. Effects of the oral treatment with Copaifera multijuga oil 
on reproductive performance of male Wistar rats. Brazilian Journal Pharmacognsosy 24:355-362.

Gonela, A., A. M. Sebbenn, H. H. Soriani, M. A. Mestriner, C. A. Martinez, and A. L. Alzate-Marin. 2013. Genetic diversity and mating system of Copaifera multijuga (Leguminosae/Caesalpinioideae). Genetics and Molecular Research 12:569-580.

Izumi, E., T. Ueda-Nakamura, V. F. Veiga, Jr, and C. V. Nakamura. 2013. Toxicity of oleoresins from the genus Copaifera in Trypanosoma cruzi: A comparative study. Planta Medica 79:952-958.

Kaina, B. 2004. Mechanisms and consequences of methylating agent induced SCEs and chromosomal aberrations: A long road traveled and still a far way to go. Cytogenetic and Genome Research 104:77-86.

Knasmuller, S., H. B. J. Steinkellner, E. C. Majer, G. Nobis, G. Scharf, and F. Kassie. 2002. Search for dietary antimutagens and anticarcinogens: Methodological aspect and extrapolation aspect and extrapolation problems. Food and Chemical Toxicology 40:1051-1062.

Kok, T. M., P. Waard, L. C. Wilms, and S. G. Van Breda. 2010. Antioxidative and antigenotoxic properties of vegetables and dietary phytochemicals: The value of genomics biomarkers in molecular epidemiology. Molecular Nutritional Food Researcher 54:208-217.

Leandro, L. F., C. C. Munari, V. L. Sato, J. M. Alves, P. F. Oliveira, D. F. Mastrocola, S. P. Martins, T. S. Moraes, A. I. Oliveira, M. G. Tozatti, W. R. Cunha, and D. C. Tavares. 2013. Assessment of the genotoxicity and antigenotoxicity of (+)-usnic acid in V79 cells and Swiss mice by the micronucleus and comet assays. Mutation Research 753:101-106.

Leandro, L. M., F. S. Vargas, P. C. S. P. Barbosa, J. K. O. Neves, J. A. Silva, and J. V. F. Veiga. 2012. Chemistry and biological activities of terpenoids from Copaiba (Copaifera spp.) oleoresins. Molecules 17:3866-3889.

Lima, S. R., V. F. Veiga, Jr, H. B. Christo, A. C. Pinto, and P. D. Fernandes. 2003. In vivo and in vitro studies on the anticancer activity of Copaifera multijuga Hayne and its fractions. Phytother Researcher 17:1048-1053.

Loh, D. S., H. M. Er, and Y. S. Chen. 2009. Mutagenic and antimutagenic activities of aqueous and methanol extracts of Euphorbia hirta. Journal Ethnopharmacol 126:406-414.

MacGregor, J. T., J. A. Heddle, M. Hite, B. H. Margolin, C. Ramel, M. F. Salamone, R. R. Tia, and D. Wild. 1987. Guidelines for the conduct of micronucleus assay in mammalian bone marrow erythrocytes. Mutation Research 189:103-112.

Majer, B. J., E. Hofer, C. Cavin, E. Lhoste, M. Uhl, H. R. Glatt, W. Meinl, and S. Knasmüller. 2005. Coffee diterpenes prevent the genotoxic effects of 2-amino-1-methyl6-phenylimidazo[4,5-b]pyridine (PhIP) and $\mathrm{N}$-nitrosodimethylamine in a human derived liver cell line (HepG2). Food and Chemical Toxicology 43:433-441.

Maron, D. M., and B. N. Ames. 1983. Revised methods for the Salmonella mutagenicity test. Mutation Research 113:173-215.
Mayne, S. T., M. C. Playdon, and C. L. Rock. 2016. Diet, nutrition, and cancer: Past, present and future. Natural Reviews Clinical Oncology 13:504-515.

Mersch-Sundermann, V., F. Kassie, S. Bohmer, W. Q. Lu, R. Wohlfahrth, R. Sobel, H. E. Brunn, M. A. Elsohly, S. A. Ross, and T. Stahl. 2004. Extract of Toxicodendron quercifolium caused genotoxicity and antigenotoxicity in bone marrow cells of CD1 mice. Food and Chemical Toxicology 42:1611-1617.

Mirzayans, R., M. Liuzzi, and M. G. Paterson. 1998. Methyl methanesulfonate-induced DNA damage and its repair in culture human fribroblasts: Normal rates of induction and removal of alkali-labile sites in Xeroderma pigmentosum (group A) cells. Carcinogenesis 12:2257-2263.

Mortelmans, K., and E. Zeiger. 2000. The Ames Salmonellal microsome mutagenicity assay. Mutation Research 455:2960.

Neigi, P. S., G. K. Jayaprakasha, and B. S. Jena. 2003. Antioxidant and antimutagenic activities of pomegranate peel extracts. Food Chemistry 80:393-397.

Nicolella, H. D., P. F. Oliveira, C. C. Munari, G. F. Costa, M. R. Moreira, R. C. S. Veneziani, and D. C. Tavares. 2014. Differential effect of manool-a diterpene from Salvia officinalis, on genotoxicity induced by methyl methanesulfonate in V79 and HepG2 cells. Food and Chemical Toxicology 72:8-12.

Niwa, A. M., N. A. De Paula, D. C. Vesenick, D. Sartori, E. L. Maistro, L. R. Ribeiro, and M. S. Mantovani. 2016. Evaluation of lignan (-)-cubebin extracted from Piper cubeba on human colon adenocarcinoma cells (HT29). Journal Toxicogical Environment Health A 79:92-100.

OECD. 2016a. Test No. 474: Mammalian Erythrocyte Micronucleus Test. Paris: OECD Publishing.

OECD. 2016b. Test No. 489: In vivo mammalian alkaline comet assay. Paris: OECD Publishing.

Oliveira De Quadros, A. P., D. E. C. Mazzeo, M. A. MarinMorales, F. F. Perazzo, P. C. P. Rosa, and E. L. Maistro. 2017. Fruit extract of the medicinal plant Crataegus oxyacantha exerts genotoxic and mutagenic effects in cultured cells. Journal of Toxicology and Environmental Health. Part A 80:161-170.

Otaguiri, E. S., A. Morguette, R. P. Biasi-Garbin, A. T. Morey, C. Lancheros, D. Kian, A. G. Oliveira, G. Kerbauy, M. R. E. Perugini, N. Duran, C. V. Nakamura, V. F. Veiga, Jr, G. Nakazato, P. Pinge-Filho, L. M. Yamauchi, and S. F. Yamada-Ogatta. 2017. Antibacterial combination of oleoresin from Copaifera multijuga Hayne and biogenic silver nanoparticles towards Streptococcus agalactiae. Current Pharmaceutical Biotechnology 18:177-190.

Resende, F. A., C. P. S. Almeida, W. Vilegas, and E. A. Varanda. 2014. Differences in the hydroxylation pattern of flavonoids alter their chemoprotective effect against direct- and indirect-acting mutagens. Food Chemistry 155:251-255.

Resende, F. A., W. Vilegas, L. C. Santos, and E. A. Varanda. 2012. Mutagenicity of flavonoids assayed by bacterial reverse mutation (Ames) test. Molecules 17:5255-5268. 
Ross, S. A. 2010. Evidence for the relationship between diet and cancer. Experimental Oncology 32:137-142.

Santos, F. V., I. M. S. Colus, M. A. Silva, W. Vilegas, and E. A. Varanda. 2006. Assessment of DNA damage induced by extracts and fractions of Strychnos pseudoquina, a Brazilian medicinal plant with antiulcerogenic activity. Food and Chemical Toxicology 44:1585-1589.

Sartorelli, P., C. S. Carvalho, J. Q. Reimão, H. Lorenzi, and A. G. Tempone. 2010. Antitrypanosomal activity of a diterpene and lignans isolated from Aristolochia cymbifera. Planta Medica 76:1454-1456.

Sasaki, Y. F., S. Tsuda, F. Izumiyama, and E. Nishidate. 1997. Detection of chemically induced DNA lesions in multiple mouse organs (liver, lung, spleen, kidney, and bone marrow) using the alkaline single-cell gel electrophoresis (comet) assay. Mutation Research 388:33-44.

Silva, J. J. M., E. J. Crevelin, L. J. Carneiro, H. Rogez, R. C. S. Veneziani, S. R. Ambrósio, L. A. B. Moraes, and J. K. Bastos. 2017. Development of a validated ultra-high-performance liquid chromatography tandem mass spectrometry method for determination of acid diterpenes in Copaifera oleoresins. Journal Chromatographic A 1515:81-90.

Sobol, Z., M. E. Engel, E. Rubitski, W. W. Ku, J. Aubrecht, and R. H. Schiestl. 2007. Genotoxicity profiles of common alkyl halides and esters with alkylating activity. Mutation Research 633:80-94.

Souza, A. B., C. H. G. Martins, M. G. Souza, N. A. J. C. Furtado, V. C. G. Heleno, J. P. Sousa, E. M. Rocha, J. K. Bastos, W. R. Cunha, R. C. S. Veneziani, and S. R. Ambrósio. 2011a. Antimicrobial activity of terpenoids from Copaifera langsdorffii Desf, against cariogenic bacteria. Phytother Researcher 25:215-220.

Souza, A. B., M. G. Souza, M. A. Moreira, M. R. Moreira, N. A. J. C. Furtado, C. H. G. Martins, J. K. Bastos, R. A. Santos, V. C. G. Heleno, S. R. Ambrósio, and R. C. S. Veneziani. 2011b. Antimicrobial evaluation of diterpenes from Copaifera langsdorffii oleoresin against periodontal anaerobic bacteria. Molecules 16:9611-9619.

Tincusi, B. M., I. A. Jiménez, I. L. Bazzocchi, L. M. Moujir, Z. A. Mamani, J. P. Barroso, A. G. Ravelo, and B. V. Hernández. 2002. Antimicrobial terpenoids from the oleoresin of the Peruvian medicinal plant. Copaifera Paupera Planta Medica 68:808-812.

Tsuboy, M. S., J. P. F. Angeli, M. S. Mantovani, S. Knasmuller, G. A. Umbuzeiro, and L. R. Ribeiro. 2007. Genotoxic, mutagenic and cytotoxic effects of the commercial dye CI disperse blue 291 in the human hepatic cell line HepG2. Toxicogical In Vitro 21:1650-1655.

Unsal, V., and E. Belge-Kurutaş. 2017. Experimental hepatic carcinogenesis: Oxidative stress and natural antioxidants. Open Access Maced Journal Medica Sciences 5:686-691.
Vargas, F. S., P. D. O. Almeida, E. S. P. Aranha, A. P. A. Boleti, P. Newton, M. C. Vasconcellos, J. V. F. Veiga, and E. S. Lima. 2015. Biological activities and cytotoxicity of diterpenes from Copaifera spp. oleoresins. Molecules 20:6194-6210.

Vargas, V. M. F., Motta, V. E. P., and Henriques, J. A. P. 1993. Mutagenic activity detected by the Ames test in river water under the influence of petrochemical industries. Mutat. Res. 319:31-45.

Veiga, V. F., Jr, E. C. Rosas, M. V. Carvalho, M. G. Henriques, and A. C. Pinto. 2007. Chemical composition and anti-inflammatory activity of copaiba oils from Copaifera cearensis Huber ex Ducke, Copaifera reticulata Ducke and Copaifera multijuga Hayne-A comparative study. Journal Ethnopharmacol 112:248-254.

Venancio, V. P., M. C. Marques, M. R. Almeida, L. R. Mariutti, V. C. Souza, F. Barbosa, Jr, M. L. Pires Bianchi, C. M. Marzocchi-Machado, A. Z. Mercadante, and L. M. Antunes. 2016. Chrysobalanus icaco L. fruits inhibit NADPH oxidase complex and protect DNA against doxorubicin-induced damage in Wistar male rats. Journal Toxicogical Environment Health A 79:885-893.

Vismara, C., and F. Caloni. 2007. Evaluation of aflatoxin $B_{1}$ embryotoxicity using the frog embryo teratogenesis assayXenopus and bio-activation with microsome activation systems. Birth Defects Research. Part B, Developmental and Reproductive Toxicology 80:183-187.

Waters, M. D., A. L. Brady, H. F. Stack, and H. E. Brockman. 1990. Antimutagenicity profiles for some model compounds. Mutation Research 238:57-85.

Witte, I., U. Plappert, H. Wall, and A. Hartmann. 2007. Genetic toxicity assessment: Employing the best science for human safety evaluation part III: The comet assay as an alternative to in vitro clastogenicity tests for early drug candidate selection. Toxicological Sciences 97:21-26.

Wyatt, M. D., and D. L. Pittman. 2006. Methylating agents and DNA repair responses: Methylated bases and sources of strand breaks. Chemical Research in Toxicology 19:15801594.

Zahin, M., I. Ahmad, R. C. Gupta, and F. Aqil. 2014. Punicalagin and ellagic acid demonstrate antimutagenic activity and inhibition of benzo[a]pyrene induced DNA adducts. BioMed Research International 2014:467465.

Zeinvand-Lorestani, H., O. Sabzevari, N. Setayesh, M. Amini, A. Nili-Ahmadabadi, and M. A. Faramarzi. 2015. Comparative study of in vitro prooxidative properties and genotoxicity induced by aflatoxin B1 and its laccasemediated detoxification products. Chemosphere 135:1-6.

Zheng, G. Q., P. M. Kenney, and L. K. T. Lam. 1992. Sesquiterpenes from clove (Eugenia caryophyllata) as potential anticarcinogenic agents. Journal of Natural Products 55:999-1003. 